DOI: https://doi.org/10.24144/2409-6857.2020.2(56).108-113

УДК 331.108.2/.3(477); 005.953.2

Кубіній Н.Ю., Варга В.П.

\title{
СУЧАСНІ ПІДХОДИ ДО ВІДБОРУ ПЕРСОНАЛУ НА ПІДПРИЕМСТВІ
}

\begin{abstract}
У статті розкрито проблему відбору персоналу на сучасних підприсмствах. Визначено актуальність питання та з'ясовано роль підбору кваліфікованого працівника. Під поняттям «підбір персоналу» розумісмо діï, що направлені на пошук відповідних кадрів, які якнайкраще зможуть досягнути поставлених иүілей та завдань, встановлені підприємством. Розглянуто традиційні (співбесіда, тестування, формування резюме, оцінювання анкетних даних та ін.) й сучасні (скринінг, рекрутинг, хедхантинг та ін.) методи відбору. Проаналізовано їх переваги та недоліки.
\end{abstract}

Ключові слова: підбір персоналу, співбесіда, резюме, скринінг, рекрутинг, хедхантинг.

Постановка проблеми. На будь-якому етапі формування економіки, підприємства займають важливу ношу у розвитку держави. Підбір персоналу, а саме кваліфікованого працівника, на сьогодні $\epsilon$ актуальною проблемою. Конкурентоспроможність підприємства, його рентабельність залежить від правильного формування кадрової політики, ефективної управлінської діяльності, створення системи мотиваційних чинників. В сучасній ринковій економіці перевага підприємства виникає не тільки завдяки сучасному технічному обладнанні, новітньому устаткуванні, але й умінню формувати людські ресурси та інтелектуальний розвиток.

Аналіз останніх досліджень і публікацій. На сьогодні спостерігається активізація наукових пошуків 3 означеної проблеми. Питання про підходи до відбору персоналу на підприємстві в Україні розглянуті у працях: О. Гетьман, В. Свтушенка, С. Клименко, Н. Кубіній, А. Лобзи, І. Лопушинського, С. Царюк, М. Чорної та ін. Відтак, А. Лобза з'ясувала теоретичні та практичні аспекти процесу найму виробничого персоналу, проблеми підбору робітників робочих професій на промислових підприємствах. Авторка наголошує на тому що: «сучасному роботодавцю важливо визначати найбільш привабливі, пріоритетні можливості залучення працівників, починаючи 3 визначення кадрової політики у профорієнтаційній роботі з молоддю» [9, с.149]. 3 погляду $\quad$ В. Мальбє [13], компанії

(С Кубіній Н.Ю., к.е.н., проф., професор кафедри економіки i підприємництва, ДВНЗ «Ужгородський національний університет», м. Ужгород, Email: njkubiniy@gmail.com

Варга В.П., магістрант кафедри економіки i підприємства, ДВНЗ «Ужгородський національний університет», м. Ужгород, Email: vargavp1981@gmail.com повинні бути укомплектовані спеціалістами, здатними успішно вирішити широкий спектр питань діяльності підприємства і разом з іншими службами активно впливати на ефективність роботи його.

Н. Кубіній доводить, що забезпечення високоефективних результатів економічної діяльності в умовах сучасних тенденцій, обумовлених впливом четвертої промислової революції, істотно залежить від людського фактору: знань і умінь людей знаходити рішення, використовувати нові технології, орієнтуватися в постійно мінливому діловому світі [7, с.119],

Дослідником вивчено сучасні методи підбору персоналу в Україні та за кордоном, окреслено алгоритм дій з цієї проблеми, сформульовано переваги тестування, рекрутингу, економікоматематичного моделювання. А. Лобза, С. Клименко зазначають, що незважаючи на сучасні кризові умови функціонування економіки України 3 надто високим рівнем безробіття, на ринку праці спостерігається недостатня кількість кваліфікованих кадрів, які б забезпечували ефективну діяльність підприємства в складних обставинах. Різноманітні методи відбору ,в більшій чи меншій мірі є ефективними. I дають можливості роботодавцю досягти поставленої мети, використавши при цьому свої ресурси [10, c. 88]. В Україні ще не великий сегмент ринку використовує інноваційні методи, але швидка зміна кон'юнктури ринку вимагає швидкого пристосування до нього.

Мета статті - проаналізувати сучасні методи підбору персоналу та обгрунтувати необхідність їхнього запровадження у системі управління підприємством. Завдання: здійснити контентаналіз поняття «відбір персонал», проаналізувати сучасні підході до відбору працівників.

Виклад основного матеріалу. Підбір та відбір персоналу - це дії, які направлені на пошук відповідних кадрів, які якнайкраще зможуть 
досягнути поставлених цілей та завдань, встановлені підприємством. Логіка нашого дослідження вимагає з'ясувати зміст ключового терміну.

Визначення терміну «відбір персоналу» у наукових джерелах

\begin{tabular}{|c|l|}
\hline Автор & \multicolumn{1}{|c|}{ Поняття } \\
\hline $\begin{array}{c}\text { А. Рекун } \\
{[15, \text { с.117] }}\end{array}$ & $\begin{array}{l}\text { комплекс різноманітних заходів з метою пошуку та відбору працівника на певні } \\
\text { вакантні посади }\end{array}$ \\
\hline $\begin{array}{c}\text { С. Кулакова, } \\
\text { О. Зотова [8] }\end{array}$ & $\begin{array}{l}\text { один з найважливіших етапів в роботі з людськими ресурсами, що включає в себе } \\
\text { розрахунок потреби в персоналі, побудова моделі компетенцій, професійний відбір } \\
\text { кандидатів і, в підсумку, формування кадрового резерву }\end{array}$ \\
\hline $\begin{array}{c}\text { В. Євтушенко, } \\
\text { М. Кудінова } \\
{[5, \text { с.158] }}\end{array}$ & $\begin{array}{l}\text { процес, що базується на вивченні професійних відповідностей кандидата до вимог } \\
\text { посади, робочого місця та відборі з претендентів найбільш підходящо, зважаючи на } \\
\text { кваліфікацію, його спеціальність, особисті якості і здібності порівняно з цілями та } \\
\text { інтересами компанії }\end{array}$ \\
\hline $\begin{array}{l}\text { О. Гетьман } \\
\text { [4, с.537] }\end{array}$ & $\begin{array}{l}\text { один з етапів системи управління персоналом, що включає в себе методи, } \\
\text { використовувані організаціями з метою забезпечення найкращого складу потенційної } \\
\text { кваліваної робочої сили, кандидатів з якої вони зможуть за необхідності найняти }\end{array}$ \\
\hline
\end{tabular}

Таким чином, дефініція «підбор персоналу» формулюється як комплекс заходів, процес, етапи управління персоналом. У контексті нашого дослідження під означеним поняттям розуміємо ряд дій, що спрямовані на залучення потенційних працівників 3 необхідними якостями до виконання цілей та завдань, що стоять перед підприємством.

Виокремимо послідовність кадрової політики 3 означеного питання: визначення потрібної вакансії, характеристика професійних навичок особистості, вибір методів пошуку кандидатів, формування резерву кандидатів, аналіз анкетних даних та оцінювання потенційних; прийом на роботу кращих. Джерелами для пошуку працівників є два види - це зовнішні та внутрішні ресурси. До внутрішніх ресурсів відноситься весь персонал, який вже залучений на виробництві даного підприємства. Ці джерела $\epsilon$ менш матеріально затратними, але цей відбір має як позитивні, так i негативні елементи. До позитивних виокремлюємо: збереження штату основного; можливість кар'єрного росту; швидке закриття вакантного місця; відсутність затрат для пошуку нового персоналу; набутті знання працівниками фахового виробництва та інші. Серед недоліків: насамперед це обмежений сегмент для вибору кадрів і це призводить до того, що не відбувається залучення людей 3 новими поглядами. До зовнішніх джерел відносимо: залучення кадрових агенцій; проведення ярмарки вакансій; співпраця з біржею праці; розміщення оголошення на радіо та телебаченні, в Інтернет мережі; залучення студентів 3 навчальних закладів та інші.

На сьогодні спостерігається використання як традиційних, так й інноваційних методів відбору персоналу на підприємстві. Наголошуємо на тому, що не можна надати перевагу конкретному методу, вказати, який з них є ідеальним. Проте визначено основоположні положення, якими слід користуватись при підборі персоналу: пошук найбільш цінних, кваліфікованих кандидатів, що підходять для робочого місця, посади; відмова від найму нових працівників незалежно від кваліфікації і особистих якостей, якщо в них немає потреби; забезпечення відповідності особистісних якостей до вимог, які потрібні для даної роботи.

Охарактеризуємо окремі традиційні методи, що мають місце на підприємствах. Вони дають роботодавцю змогу отримати якомога більш повну інформацію про претендента на посаду, а також розкривають основні риси характеру претендента. завдяки цим методам роботодавець ще до прийняття кандидата на посаду може оцінити, чи придатна людина для роботи в компанії чи на підприємстві, чи не придатна [5, c.159].

Аналіз анкетних даних - найпростіший метод, за якого роботодавець не має змоги дізнатись про всі можливості працівника. Зазвичай використовують загальні питання, де подаються стислі відомості про працівника.

Центри оцінювання - не мають широкого розповсюдження. 3 погляду $\quad$ В. Свтушенко, М. Кудінова цей метод являє собою вид тренінггри, у якій претендент знаходиться в ситуації, максимально наближеній до робочої обстановки [5, c. 160].

Тестування. В. Біндюженко сформульовано переваги означеного методу, що полягає у можливості оцінки сучасного стану кандидата 3 врахуванням особливостей організації та майбутньої посади [2]. За допомогою цього методу можна дізнатись про охайність, вміння раціонально розподілити свій час. Важливим $\epsilon$ те, що всі учасники є в однакових умовах, ніхто не 
має ніякої переваги. Тести для визначення рівня знань і навичок покликані проаналізувати коло умінь та знань претендента, ранжувати їх на посаду.

Співбесіда - поширений метод, що дозволяє за короткий час встигнути побачити та проаналізувати компетентності працівника, його морально-етичні якості, можливий потенціал та здібності. Співбесіду може проводити не тільки роботодавець, але також і менеджер з кадрів. Під час цього способу проходить безпосередній контакт між сторонами, тому тут важливим $є$ все, починаючи зі зовнішнього вигляду. На сьогодні поширеним $є$ практика онлайн співбесіди, що уможливлюють скоротити час на пошук потенційного працівника на підприємства. Визначено [14, с.340] плюси онлайн співбесіди: економія грошей на дорогу; немає територіальної прив'язки, тобто людина, яка шукає роботу, може бути 3 іншого міста або навіть 3 іншої країни; завершити співбесіду простіше, використовуючи правила ділового етикету. Серед недоліків: якість проведення залежатиме від технічного стану пристроїв і у людини, яка шукає роботу i у працедавця; не дає можливості оцінити місце роботи i обстановку на підприємстві. Після проходження онлайн співбесіди, кандидатури, що зацікавили працедавця, запрошуються на очну співбесіду на підприємство. Резюме - письмова форма подання без конкретної форми оформлення, метою якого $\epsilon$ зацікавити роботодавця саме до себе, вказати свої переваги, перспективи, які б вважались пріоритетними.

Погоджуємось 3 позицією В. Занори [6, с.9091] про те, що з кожним роком зростають вимоги до працівників, оскільки ситуація на ринку праці змінюється, підприємства розвиваються та розширюються, i, відповідно використання лише традиційних резюме та співбесід для виявлення необхідних якостей потенційних співробітників $\epsilon$ недостатнім. Не дивлячись, на те що методів відбору $є$ багато. Для найкращого і якісного підбору персоналу роботодавці використовують нетрадиційні методи.

До інноваційних методів відбору не всі роботодавці готові, як психологічно, так i матеріально, адже деякі форми відбору потребують великих капіталовкладень. Подамо позиції окремих авторів щодо змісту основних методів.

Таблиця 2

Інноваційні методи відбору персоналу

\begin{tabular}{|c|c|}
\hline Метод & Характеристика \\
\hline Хедхантінг & $\begin{array}{l}\text { виявлення та залучення в організацію сильних кандидатів, які самостійно не шукають } \\
\text { перспективну роботу [ } 1, \text { с.275]; } \\
\text { конкретного спеціаліста з конкретної компанії, який є рідкісним, як за фахом, так і за } \\
\text { рівнем професіоналізму [11. с.77]; } \\
\text { пошук і відбір керівництва вищої ланки (у суворій конфіденційності), «переманювання» } \\
\text { визначеного ексклюзивного спеціалісту (відоме ім’я та посада) для компанії-замовника } \\
\text { [8]. }\end{array}$ \\
\hline Скринінг & $\begin{array}{l}\text { відбір потенційних працівників відбувається за формальними ознаками (віком, статтю, } \\
\text { освітою, приблизним досвідом роботи) і здійснюється самим підприємством за } \\
\text { допомогою надсилання запиту до служби зайнятості, розміщення оголошень про } \\
\text { вакансію в Інтернеті, 3МІ }[15, \text { с.116]; } \\
\text { це масовий підбір кандидатів шляхом фільтрації всього потоку резюме шукачів по } \\
\text { формальним вимогам (стать, вік, освіта, досвід роботи, готовність розглядати } \\
\text { пропозиції про роботу) [8]. }\end{array}$ \\
\hline Рекрутмент & $\begin{array}{l}\text { передбачає підбір кадрів з урахуванням реальних особливостей робочого місця та } \\
\text { ділових, особистісних якостей кандидата, що здійснюється за допомогою наявної бази } \\
\text { кандидатів і по відгукам на оголошення в ЗМІ [15, с.116]; } \\
\text { комплекс організаційних заходів, спрямованих на пошук і підбір такого персоналу, якій } \\
\text { за своїми професійними, психологічними та фізіологічними якостями відповідає посаді } \\
\text { та який в даний момент необхідний для компанії замовника [8]; } \\
\text { технологія добору персоналу, що забезпечує пошук кваліфікованих фахівців середньої } \\
\text { ланки } з \text { урахуванням вимог до особистісних та професійних якостей кандидатів, } \\
\text { використовуючи наявні бази кандидатів й надаючи оголошення в 3МІ [11, с.77]. }\end{array}$ \\
\hline Краудсорсинг & $\begin{array}{l}\text { передача роботи не професіоналам, а низькооплачуваним або неоплачуваним } \\
\text { любителям-професіоналам, які отримують завдання зазвичай через мережу Інтернет та } \\
\text { витрачають на їі виконання свій вільний час }[1, \text { с. } 275] \text {. }\end{array}$ \\
\hline
\end{tabular}


Отже, спостерігаються новітні можливості, проте поруч з цим виокремлюємо моменти, на які слід звернути увагу: навчання нового персоналу; невідповідність людини відповідній посаді; неможливість пристосуватись до колективу; небажання вчитись; довгий період адаптації.

На думку Г. Рекун «хедхантинг розрахований на так званих «золотих комірців» - вищих керівників (керівників підприємств, топменеджерів), рекрутинг - на «білих комірців» (наприклад, керівників відділів), а скринінг використовують підбору допоміжного та обслуговуючого персоналу. Застосування інноваційних методів прогнозує конкретні потреби підприємства . Кожен $з$ поданих вище методів враховує вимоги конкретного роботодавця і закриває кадрові вакації ті, в яких є потреба» [15 c.116]. Хедхантинг - найдорожчий метод підбору персоналу і часто призводить до переманювання досвідченого фахівця до свого виробництва. Деякі менеджери відмовляються від цього методу, через соціальний аспект. Адже для досягнення поставленої мети в хід використовують всі можливі дії.

Основним завданням рекрутингу $\epsilon$ можливість розвиватку завдяки великому вибору рекрутингових агенцій, які $є$ майже в кожному місті. Доступ до багатьох інформаційних баз, дають змогу зробити ретельний аналіз і підібрати саме той персонал, якого потребує підприємство. Глобалізація у всіх сферах інформаційного простору надає змогу міграції кваліфікованого працівника з одного регіону в інший.

Метод скринінгу, на думку I. Лопушинського[12], зазвичай використовується в бізнесі. Водночас застосовують при доборі молодшої ланки персоналу, наприклад водіїв, продавцівконсультантів, секретарів, бухгалтерів, менеджерів 3 продажу. Проте часом скринінг використовують, набираючи й середню ланку компанії. Скринінг зачасто застосовують для того, щоб позбутись зайвих претендентів, робиться фільтрація поданих даний для пошуку персоналу саме тих працівників, в яких зацікавлений роботодавець. Ця методика обирає 3 безлічі поданих резюме на співбесіду вже конкретного претендента на посаду. Це допоміжний захід для надання переваги кандидату.

Особливе значення набір кадрів набуває в креативних сферах бізнесу, коли творчість, мобільність мислення, ерудиція стають основними якостями працівника, необхідними для вирішення виробничих завдань. Для виявлення вказаних якостей рекомендуємо застосовувати спосіб, якій ми називаємо «метод кросвордів»; він полягає в наступному:

- 1 етап. Корпорація виставляє на платформах, що діють на ринках праці, власний сайт, на якому проводиться конкурс серед читачів на переможця 3 розгадування серії кросвордів. Визначається велика премія особами, які найшвидше та найбільшу кількість кросвордів розгадають.

- 2 етап. Переможців запрошують в офіс компанії для нагородження, при цьому здійснюють збір додаткової, але необхідної інформації (коло інтересів, творчих здібностей, життєвих цільових установок і т.д.- в залежності від кадрової стратегії підприємства).

- 3 етап. Проводиться реклама власної фірми, аргументують переваги працівників даного бізнесу.

- 4 етап. Проводиться набір працівників 3 кола учасників конкурсу кросвордів.

Сьогодні не можна сказати, який $з$ методів $\epsilon$ доцільним. Тому перед тим, як обрати підхід роботодавець має чітко розуміти на які саме посади і яку кількість персоналу йому потрібно. Вважаємо, що інноваційні методи нададуть змогу розкрити скриті можливості людини, дозволять виявити харизму людину, а також нахили до творчої діяльності. Ці та інші показники $€$ перевагою для прийому на роботу, адже креативне мислення та стресостійкість, наполегливість, рішучість $є$ необхідними якостями у майбутній професійній діяльності .

Наведені методи оцінювання кандидатів під час відбору можуть забезпечити керівництво широкою інформацією про можливості конкретного працівника, однак вони не можуть дати відповіді на важливе запитання, чи буде людина повністю реалізовувати свої знання i можливості [4, с. 541]. Авторами зазначено , що однієї найуніверсальнішої методики відбору кандидатів не існує.

Висновки та перспективи подальших досліджень. Отже, нами проаналізовано сучасні методи підбору персоналу; здійснено контентаналіз поняття «відбір персонал», проаналізувати окремі традиційні та інноваційні підходи. Аналіз наукових досліджень засвідчив, що перевагу надавати краще відразу декільком способам відбору, для того щоб якнайширше відкрити потенціал працівника, тому що сьогодні вимоги роботодавця $\epsilon$ високими. Адже, жоден 3 наведених методів не має змоги розкрити всі можливості та перспективи людського ресурсу. Персонал $\epsilon$ вагомим важелем, який надає стабільності, розвитку, збільшення прибутку, примноження продуктивності підприємству, саме 
професіоналізм працівників $є$ запорукою його фінансової стабільності.

Перспективи подальших досліджень вбачаємо у визначенні нематеріального умовах. системи матеріального та стимулювання в сучасних

\section{ПЕРЕЛІК ВИКОРИСТАНИХ ДЖЕРЕЛ}

1. Ачкасова О., Семенченко А. Сучасні методи формування персоналу вітчизняного підприємства / O. Ачкасова, A. Семенченко URL: http://www.repository.hneu.edu.ua/bitstream/123456789/19149/1/\%D0\%9E. (дата звернення 12.02.2020)

2. Біндюженко В. М. Система набору та відбору персоналу організації та формування кадрової політики / B. М. Біндюженко Електронний журнал «Ефективна економіка» від 11.07.2019 № 975, URL: http://www.economy.nayka.com.ua/?op=1\&z=5602 (дата звернення 12.02.2020)

3. Вакуленко Т. В. Сучасні аспекти теоретичних підходів до управління персоналом / Т. В. Вакуленко // Науковий вісник Полтавського університету економіки і торгівлі. Випуск 4 (55), 2012. С. 144-147.

4. Гетьман О .О. Управління підбором і наймом персоналу на підприємстві (організації) / O .О Гетьман, С. Ю. Царюк // Глобальні та національні проблеми економіки. Випуск 21.2018. С. 536-541.

5. Євтушенко В. А. Кудінова М. М. Інноваційні методи відбору персоналу в сучасних умовах / В. А. Євтушенко, М. М. Кудінова, К. О. Лазарєва // Східна Європа : економіка, бізнес та управління. Випуск 3 (08), 2017. C. 158-164.

6. Занора В .О. Управління кадрами: узагальнення методичного інструментарію відбору працівників / В. О. Занора, С. В. Драч // Економічний вісник Запорізької державної інженерної академії. Випуск 5-1 (05), 2016. C. 89-92.

7. Кубіній Н .Ю. Субєктно-обєктний підхід в системі управління трудовим потенціалом / Н .Ю .Кубіній, А.О. Нечипорук, М. Ю.Бабяк, А.В. Косовілка // Науковий вісник Ужгородського Університету Серія Економіка. Випуск №2 (52), 2018 р. С.119-123.

8. Кулакова С. Ю. Управління процесом рекрутингу на підприємствах в сучасних умовах / С. Ю. Кулакова, В. В .Копейкіна, О.М. Зотова Електронний журнал «Ефективна економіка» від 11.07.2019 № 975 . URL: http://www.economy.nayka.com.ua/?op=1\&z=6054 (дата звернення 11.02.2020)

9. Лобза А. В. Організація процесу найму персоналу на сучасному українському підприємстві / А. В. Лобза, С. К. Комарова // Причорноморські економічні студії. Випуск 11. 2016. С.144-149

10. Лобза А. В., Клименко С. Ю. Особливості підбору персоналу на сучасних українських підприємствах, тенденції розвитку рекрутингу / А .В. Лобза, С. Ю. Клименко // «Молодий вчений» № 5 (32), травень, 2016. C. 87-90.

11. Лобза А. В., Юрченко К. А. Сучасні персонал-технології як засіб забезпечення ефективної системи найму та адаптації персоналу: вітчизняний та зарубіжний досвід / А.В.Лобза, К .А. Юрченко // «Молодий вчений» № 7611 (26), Частина 2 , листопад, 2015. С. 74-79.

12. Лопушинський І. П. Кадровий скринінг публічних службовців : виклики реформування державної служби в Україні / I .П. Лопушинський // Теорія та практика державного управління і місцевого самоврядування 2014 № 2, URL: http://el-zbirn-du.at.ua/2014_2/19.pdf (дата звернення 12.02.2020)

13. Мальбє В. В. Професійний підбір кадрів як запорука успішної діяльності підприємства // Науковий огляд № 4 (36), 2017. URL: http://oaji.net/articles/2017/797-1496297643.pdf (дата звернення 11.02.2020)

14. Мутерко Г. М. Сучасний метод підбору трудового ресурсу на промислове підприємство // Вісник Приазовського державного технічного університету. Серія: Економічні науки. Випуск 34, 2017. С.336-341

15. Рекун Г.П. Особливості використання технологій підбору персоналу на підприємстві / Г. П.Рекун, Я. С. Маліновская // Науковий вісник Міжнародного гуманітарного університету Випуск 12, 2015. С.114-118.

\section{REFERENCES}

1. Achkasova O. V., Semenchenko A. V. (2018). "Modern methods of personnel formation of a domestic enterprise", Mizhnarodnoyi naukovo-praktychnoyi konferenciyi "Ekonomichnyj rozvytok i spadshhyna Semena Kuznecya" [Online], pp.274-275 available http://www.skced.hneu.edu.ua/files/tez_konferencii_simon_kuznets_14_05_18.pdf\#page=274 (Accessed 12 February 2020) [ in Ukrainian].

2. Bindyuzhenko V. M.(2019) "System of recruitment and selection of personnel of organization and formation of personnel policy". Elektronnyj zhurnal «Efektyvna ekonomika» [Online], vol.975 available at URL: http://www.economy.nayka.com.ua/?op=1\&z=5602 (Accessed 12 February 2020). [in Ukrainian].

3. Vakulenko T. V. (2012). "Modern aspects of the theoretical approaches to personnel management", Naukovyj visnyk Poltavskogo universytetu ekonomiky i torgivli, vol. 4(55), pp. 144-147. [in Ukrainian].

4. Getman O.O., Czaryuk S. Yu.(2018) "Recruitment and hiring management of personnel at the enterprise (organization)", Globalni ta nacionalni problemy ekonomiky, vol.21, pp.536-541. [in Ukrainian].

5. Yevtushenko V .A. ,Kudinova M .M. , Lazaryeva K .O.,(2017) "Innovative methods of the staff selection in the modern conditions". Sxidna Yevropa : ekonomika, biznes ta upravlinnya, vol.3(08), pp. 158-164. [in Ukrainian]. 
6. Zanora V. O., Drach S. V., (2016) "Personnel management: systematization of staff selection methodical toolkit”. Naukovyj visnyk Uzhgorodskogo Universytetu Seriya Ekonomika, vol. 5-1(05), pp.89-92. [in Ukrainian].

7. Kubinij N.Yu., Nechyporuk A. O., Babyak M. Yu. , Kosovilka A. V.(2018) "Subject-object approach in the labor management system potential”. Naukovyj visnyk Uzhgorodskogo Universytetu Seriya Ekonomika, vol. 2 (52), pp. 119-123. [in Ukrainian].

8. Kulakova S. Yu , Kopejkina, V.V . ,Zotova O. M. (2019) "The management of the recruitment process at enterprises in modern conditions". Elektronnyj zhurnal «Efektyvna ekonomika» vol.975, available at URL:

http://www.economy.nayka.com.ua/?op=1\&z=6054 (Accessed 11 February 2020). [in Ukrainian].

9. Lobza A. V., Komarova S. K. (2016) "Organization of recruitment in the modern ukrainian enterprise". Prychornomorski ekonomichni studiyi, vol. 11, pp. 144-149. [in Ukrainian].

10. Lobza. A. V, Klymenko. S. Yu.(2016) "Features of staff selection to modern ukrainian enterprises, development trends recruiting". «Molodyj vchenyj», vol.5 (32), pp.87-90. [in Ukrainian].

11. Lobza A. V., Yurchenko K .A.(2015) "Modern staff technology as a means of ensuring an effective system of hiring and adaptation of personnel: domestic and foreign experience". «Molodyj vchenyj», vol.11(26), part 2, pp.74-79. [in Ukrainian].

12. Lopushynskyj I. P. (2014) "Personnel screening of civil servants: challenges of civil service reform in Ukraine". Teoriya ta praktyka derzhavnogo upravlinnya i miscevogo samovryaduvannya, vol. 2, available at URL: http://el-zbirndu.at.ua/2014_2/19.pdf (Accessed 12 February 2020). [in Ukrainian].

13. Malbye V. V.(2017) "Professional recruitment as a guarantee of success of the enterprise". Naukovyj oglyad, vol. 4 (36), available at URL: http://oaji.net/articles/2017/797-1496297643.pdf (Accessed 11 February 2020). [in Ukrainian].

14. Muterko G. M. (2017) "Modern method of selection of labor resource at an industrial enterprise". Visnyk pryazovskogo derzhavnogo texnichnogo universytetu Seriya: Ekonomichni nauky, vol.34, pp.336-341. [in Ukrainian].

15. Rekun G. P,Malinovskaya Ya. S.(2015) "Features of the applicationof recruitment technologies staffing company", Naukovyj visnyk Mizhnarodnogo gumanitarnogo universytetu, vol.12, pp.114-118. [in Ukrainian].

Отримано 30.11.2020 